\title{
Like father, like son? Power and influence across two Gnassingbé presidencies in Togo
}

\author{
Anja Osei
}

Department of Politics and Public Administration, University of Konstanz, Konstanz, Germany

\begin{abstract}
In personalized authoritarian systems, the death of a leader poses a serious challenge to regime survival. Togo, however, belongs to a small number of countries in which regime collapse has been avoided by the transfer of power to the deceased ruler's son. But can the son simply pick up where the father left off? Combining a theoretically guided single case study with statistical network analysis, this article argues that hereditary succession involves both changes and continuities. While Gnassingbé Eyadema's rule rested on repression, patronage, and a bizarre leadership cult, his son Faure Gnassingbé has partly adapted and reformulated these strategies. The quantitative part of the article is based on a novel data set that contains information on the biographical characteristics and interaction patterns of the deputies in the Togolese parliament. Using exponential random graph models (ERGMs), the article shows that people who have held important positions in the past or belong to the president's ethnic group still play a significant role in the regime elite. The article not only presents detailed insights on a so far underresearched country, but also contributes to the wider literature by showing how mixed-method designs can further our understanding of authoritarian regimes.
\end{abstract}

KEYWORDS electoral authoritarianism; Togo; Africa; succession; patronage; repression; personalism; co-optation

\section{Introduction}

In 2005, Gnassingbé Eyadema died after having ruled Togo for 38 years. The army subsequently installed his son, Faure Gnassingbé, as the president of Togo. Protests erupted in the capital Lomé, with opposition groups, youths, and civil society organizations expressing their discontent about the unconstitutional transfer of power. Nevertheless, the ruling party closed its ranks in favour of the transition. In fact, the cadres of the old regime stood up "like one man"1 to support the presidency of Faure Gnassingbé.

Such a high degree of elite cohesion cannot be taken for granted because personalized authoritarian regimes with highly centralized power structures are vulnerable to collapse due to succession crises. ${ }^{2}$ At the same time, however, this regime type is relatively unlikely to democratize. Among scholars of authoritarian politics, it has become commonly accepted that leadership change does not necessarily lead to improved democracy, and that political transitions can also occur from one authoritarian type 
to another. ${ }^{3}$ Due to their opaqueness, however, we know relatively little about change and continuity in the internal dynamics of autocratic regimes.

Togo is an interesting case of a "seamless passage of power from one autocratic ruler to his preferred heir" 4 as it allows us to study the strategies of two successive rulers. This invites questions such as:

(a) How and why did the regime survive, that is, what changes and continuities in authoritarian rule in Togo can be identified?

(b) Who are the current ruling elites in Togo, and how has this group changed as a result of the transition?

To answer these questions, this article uses a mixed-methods design that combines a theoretically guided case study with statistical network analysis. While the qualitative section describes and compares the legitimation strategies of authoritarian rule under Gnassingbé Eyadema and Faure Gnassingbé, respectively, the quantitative section uses a unique data set collected in the Togolese National Assembly in 2014. These data include information not only on the biographies and career patterns of the members of parliament but also their communication structures and interactions. By providing a snapshot of the elite configurations, an analysis of the data set can help us to understand the dynamics of Togo's current ruling coalition.

The article contributes to the wider debate on authoritarianism in two ways. First, it suggests a new way to empirically study elite interactions in authoritarian countries. Second, it discusses continuity and change in a highly personalized system and shows how legitimation strategies must be adapted after the death of a ruler.

\section{Authoritarian sub-types and transitions}

Regime transitions can entail a change from autocracy to democracy but also from one authoritarian type to another. This section briefly discusses three different regime classifications and situates Togo as a case study in this debate. ${ }^{5}$

First it is necessary to clarify the meaning of the term "elite". As with many other social science concepts, there is no unanimously accepted definition. To avoid confusion, this article follows Higley and Burton ${ }^{6}$ by defining elites as "persons who are able, by virtue of their strategic positions in powerful organizations and movements, to affect political outcomes regularly and substantially". This broad definition not only includes business, government, and military leaders, but also top position holders in parties, professional associations, and interest groups.

The question of who determines political outcomes also underlies Geddes ${ }^{77}$ typology of authoritarian regimes and their different propensities for survival and democratization. She distinguishes between three types: military, single-party, and personalist regimes. In military regimes a group of officers decides who will rule, in single-party regimes the dominant party controls the access to spoils and political office, ${ }^{8}$ and in personalist regimes access to office depends on the discretion of an individual leader. Whereas military regimes often fall victim to internal splits, factions in single-party and personalist regimes have stronger incentives to cooperate. Personalist regimes are especially vulnerable to economic crises and the death of the dictator; moreover, they are also the least likely to democratize. ${ }^{9}$ These claims have been corroborated by numerous subsequent studies. ${ }^{10}$ 
Geddes' work has inspired an ongoing debate on regime classification, with her treatment of personalism as a unique regime type attracting particular criticism. Wahmann, Hadenius, and Teorell ${ }^{11}$ view personalism as a continuous trait that may be more or less present in any given regime. Their own typology distinguishes between authoritarian regimes without elected legislatures (monarchies or military regimes) and authoritarian regimes with elected legislatures (no-party, one-party, or multiparty authoritarian). The multiparty authoritarian regime type corresponds to Schedler's "electoral authoritarianism", 12 denoting regimes that hold regular elections but simultaneously violate liberal-democratic principles. In discussing various regime classifications, Kailitz ${ }^{13}$ reintroduces the category of the personalist regime but reserves it for countries in which the head of state is not chosen in popular elections.

The usefulness of regime classifications for large-N studies is undeniable. All approaches discussed here attempt to make sense of the diversity of authoritarian regimes, and all three put forward meticulous arguments for their typologies. When they are applied to a case like Togo, however, it becomes obvious how difficult it is to capture the complex and shifting realities with these categories. Examining the data sets compiled by Geddes; Wahmann, Hadenius, and Teorell; and Kailitz, one might conclude that Togo combines all of the above categories: personalism, military dominance, and single-party rule. In an updated version of her data set, ${ }^{14}$ Geddes classifies Togo as a personalist regime across the country's entire history. This would mean that Faure Gnassingbé governs in much the same way as his father did, and that no significant changes have taken place. Wahman, Teorell, and Hadenius ${ }^{15}$ classify Togo under Gnassingbé Eyadema as a military regime (one-party military until 1990 and multiparty military after a transitional period from 1990 to 1993) that evolved into a limited multiparty system after the hereditary transfer of power. This suggests that Togo has experienced more than one transition from one authoritarian sub-type to another. For Kailitz, Togo falls into the category of the personalist regime from 1967 to 1990 and becomes an electoral autocracy from 2004 onwards. ${ }^{16}$

Because this article does not focus on regime typologies per se, no alternative classification for Togo will be proposed. The argument is that we need an iterative dialogue between case-based research and classificatory studies in order to refine our categories. Since cases for qualitative or quantitative work are often chosen on the basis of typologies, these must be empirically well-grounded. Given the fact that Togo is extremely under-researched, it is not surprising that the regime cannot be unambiguously classified. This demonstrates one of the major weaknesses of the current literature on authoritarianism: Due to the opaqueness of non-democratic regimes, we often know very little about their internal logic. The article will therefore open the black box of authoritarian rule, change, and continuity in Togo. As a theoretical guideline, I will use Gerschewski's "pillars of stability"17 to describe the politics of the country.

\section{Sources of stability and instability in personalized regimes}

All autocratic regimes, irrespective of their type, rely on a combination of legitimation, repression, and co-optation. ${ }^{18}$ Repression is the backbone of authoritarian rule, but even the most repressive regimes must develop a legitimation strategy. In addition to nationalism, or any form of official state ideology, this can be rooted in performance, for example, in socio-economic development or security. ${ }^{19}$ In addition, authoritarian 
rulers seek to co-opt strategically relevant actors by rewarding their loyalty with access to material benefits. ${ }^{20}$

The "pillars of stability" theory is applicable to all autocracies, but there is also reason to believe that the actual combination of strategies differs across authoritarian regime types. With regard to legitimation, personalized systems may exhibit a distinct ideology or legitimize themselves by providing collective goods such as economic prosperity or political stability, but they typically also build up a personality cult. Schatzberg ${ }^{21}$ has described how African leaders invoke paternal images to present the nation as a family and the president as the "father" of this family. These personality cults are often rooted in local cosmologies and spiritual belief systems like occultism and witchcraft. $^{22}$ By attributing supernatural powers to themselves, rulers not only articulate a strong claim to power but also threaten and deter their opponents. This suggests that personality cults in authoritarian regimes are inextricably linked to repression. Personalized systems employ the full range of repressive instruments: restrictions on the freedom of speech, information, and assembly, violently crushing opposition protest, or jailing political opponents. It is worth noting, however, that repression is often also directed against members of the ruling elite. In a bid to prevent the emergence of alternative power centres, rulers frequently rotate their political personnel, and opponents are expelled and forced to take refuge in exile. ${ }^{23}$ This creates a sense of persistent insecurity and makes the emergence of coordinated rival factions unlikely. ${ }^{24}$

Co-optation, the third pillar of stability, thus plays a crucial rule for a dictator's ruling coalition. Personalist rulers typically rely on the support of a small clique of strategic elites, who may be members of a certain ethnic group or even family members. ${ }^{25}$ The political loyalty of these individuals is exchanged for access to material benefits. Although the ruling coalition in such regimes is narrow, scholars of African studies often emphasize that elite co-optation and patronage have a close link to mass patronage because political representatives in Africa are generally expected to care for the wellbeing of their home communities. ${ }^{26}$ In other words, if a member of a group has made it to the inner circle of the regime, his or her fellow ethnics might see this as a sign that their interests are being served and that they will receive their fair share of the "national cake". ${ }^{27}$

Their reliance on patronage distribution makes personalist regimes extremely vulnerable to economic crises. ${ }^{28}$ In addition, personalized systems rarely survive long after the death of the ruler. ${ }^{29}$ Given the extreme informalization and centralization of these regimes, an unexpected death can create a power vacuum that poses an imminent risk of regime collapse. Given the lack of established precedents for political successions, elites in these countries may prefer the transfer of power to a close relative of the deceased dictator to an unconstrained power struggle. ${ }^{30}$ This suggests two things: Successor regimes are able to uphold authoritarian rule, and crucial elites remain loyal to the heir. From this observation, two interrelated questions arise:

(a) How and why did the regime survive, that is, what changes and continuities in authoritarian rule in Togo can be identified?

(b) Who are the current ruling elites in Togo, and how has this group changed as a result of the transition?

In order to answer these questions, this article combines a qualitative and a quantitative approach, both of which will be described in Section 4 . 


\section{Method}

In this article, a descriptive case study is combined with statistical network analysis. ${ }^{31}$ The qualitative and quantitative data are given equal weight in the article but are analysed separately and only combined in the interpretation. ${ }^{32}$

Before any single case study can be conducted, the universe of cases must be defined. Togo is an electoral authoritarian regime that belongs to a small group of cases that have experienced non-monarchic hereditary succession from father to son. Within this group, Togo is a typical case; that is, it "is representative in the sense of being able to generalize insights from it to similar cases in the population". ${ }^{33}$ The qualitative part of the article is a detailed description of the continuities and changes in Togo guided by Gerschewski's theory of the three "pillars of stability". This case description informs the hypotheses for the statistical network analysis, which are then tested on a unique data set. Data collection took place in Togo in 2014 and 2015 in close collaboration with the Centre de Recherche et de Sondage d'Opinions (CROP). The fieldwork included a quantitative survey of political elites supplemented by a small number of qualitative in-depth interviews with selected individuals (journalists, members of the ruling party, and the opposition). The qualitative interviews provide additional and background information, whereas the quantitative part is designed to shed light on the biographical characteristics of the Togolese political elite and their networks of interaction. This is a difficult task because authoritarian states are characterized by informality, ${ }^{34}$ and the networks of power are not directly observable and therefore hard to uncover. The challenge is thus to identify a relevant group of political actors whose informal interactions can be measured with the tools of social network analysis. Using the positional method that identifies elites according to the formal positions they hold, members of parliament (MPs) were chosen as the target group.

A number of steps had to be taken to ensure the collaboration of the MPs. In meetings between party representatives, the research team explained the objectives of the study and assured the MPs that all data would be used for scientific purposes only and that no sensitive information connected to individual names would be published. A high response rate of $79 \%$ was achieved.

MPs were interviewed using a standardized questionnaire. Two types of data were collected: attribute data (biographical data, career patterns, and values) and relational data. In the biographical part, MPs were asked to indicate whether they

(a) had ever held a position in the political sector before being elected to parliament,

(b) had ever held a high-ranking position in the economic, social, traditional, or security sector, and

(c) whether they had relatives who have held or currently hold a high-ranking position in any one of these sectors.

For the collection of the relational data, a name generator was used: "Looking back over the last six months, who are the people in the Parliament of Togo with whom you have discussed important political decisions? Please give me their names." A similar question was first used in the General Social Survey (GSS) and has since become a standard tool for obtaining network information. ${ }^{35}$ On average, MPs named five fellow MPs as discussion partners. From these ego networks, a full network of interactions was constructed. The Togolese network is directed, meaning that the ties have a direction 
from actor $i$ to actor $j$ or from actor $j$ to actor $i$. Actors who receive a high number of incoming ties (in-degrees) are prominent or prestigious in the network as they are highly sought-out as the object of relations. ${ }^{36}$ Prestigious actors can be assumed to be members of the core regime elite. Because in-degrees can tell us who is influential in the network, they are used for the statistical network analysis described in Section 7. The combination of this information with data on actors' attributes allows us to analyse the formation of ties in the network.

Because social network data violate the assumptions of many conventional statistical procedures, specialized statistical models known as exponential random graph models (ERGMs) are required. The central idea is that network ties depend on one another and are at the same time influenced by actor attributes and other exogenous factors. ${ }^{37}$ Essentially, ERGMs compare an observed network to a large number of random networks by modelling the effects of interest and identifying a distribution of graphs in which the observed data are central in the distribution. ${ }^{38}$ The models are fitted via Markov Chain Monte Carlo Maximum Likelihood Estimation (MCMC MLE). The dependent variable is the log odds of establishing a network tie. Coefficients are interpreted as log-odds ratios conditional on the rest of the network. Before applying these methods to the data set, the next section will present a qualitative account of politics in Togo.

\section{Togo under Gnassingbé Eyadema}

\subsection{Legitimation}

Eyadema's rule relied upon a number of interrelated legitimacy narratives. One legitimation strategy presented Togo as a land of stability and prosperity. ${ }^{39} \mathrm{In}$ fact, the country was relatively well-off in the 1970s and 1980s and has never experienced a civil war or large-scale conflict. This discourse cannot be separated from the myth that surrounded the leader himself. In his early years, Eyadema claimed to have "saved" Togo from the ethnically imbalanced government of the nation's first president, Sylvanus Olympio. The over-proportional representation of Ewe and Mina from the south of the country was in part a consequence of an historic north-south development gap inherited from the colonial era. ${ }^{40}$ Administrative staff were largely recruited from the southern ethnic groups; consequently, military careers were one of the few paths to social advancement for the northern ethnic groups. ${ }^{41}$ The first military coup, in which Olympio was assassinated, was led by soldiers from the disadvantaged north. The succeeding civilian government, led by Olympio's rival Grunitzky, was weak and incapable of resolving the power struggles between the various elite factions. This led to the second military takeover in 1967 led by Gnassingbé Eyadema, where a military council seized political power, dissolved the National Assembly, and banned all political parties except the newly created ruling party RPT (Rassemblement du Peuple Togolais). Eyadema presented his ascendancy to power as the will of $\operatorname{God}^{42}$ and began to model himself as a ruler with supernatural powers. Having come to power on 13 February 1967, he created a cult around this date and especially the number $13 .{ }^{43}$ The myth concerning Eyadema's alleged supernatural powers was perpetuated by the Sarakawa incident: In 1974, the president's plane crashed near his hometown Pya, killing all on board except Eyadema himself. A mausoleum was erected around the remains of the airplane, which then served as a site for the regular performance of secret rituals. As Toulabor ${ }^{44}$ 
describes, regime stalwarts dressed in white robes would sacrifice sheep to form an alliance between the Togolese people and the "miracle of Sarakawa". To construct the cult, Eyadema heavily borrowed from local belief systems and religious motives, merging them with a postcolonial conception of personalized, sacrificed, and indivisible power. ${ }^{45}$

Two other motives are connected to the Sarakawa incident: anti-imperialism and authenticité. Because the plane crash coincided with a dispute over the phosphate trade between France and Togo, Eyadema accused France of trying to kill him. ${ }^{46}$ As a result he announced a policy of nationalization and began to portray himself as a fighter against imperialism. Although the country's relationship with France quickly normalized, the Sarakawa incident had an impact on the way power was conceptualized and displayed under Eyadema, perpetuating the image of an invulnerable and immortal leader.

\subsection{Co-optation and patronage}

Eyadema administered Togo like his personal property and distributed favours to everyone who supported his regime. RPT loyalists received benefits such as lucrative jobs, bank loans, study credits, or commercial monopolies. ${ }^{47}$ As the fifth-largest producer of phosphates worldwide, Togo enjoyed a period of economic growth in the early years of Eyadema's rule. In addition, Western powers provided generous development aid and military assistance to the regime, which they viewed as a bulwark against socialist experiments in the neighbouring West African countries. A third source of resources for clientelistic redistribution was the Port of Lomé, one of the biggest and safest harbours in the region, which generated high tariff revenues.

Attisso describes clientelism in Eyadema's Togo as highly personalized. ${ }^{48}$ Every day, he writes, people queued in front of the president's residence in Lomé to present their real or fake project plans to the dictator. If he liked the idea, Eyadema would send his son Faure to the family safe to hand over this or that sum of money to the applicant. ${ }^{49}$ Sometimes, instead, he would send the applicant to the director of the port, who was required to provide the requested money from his funds. ${ }^{50}$

Corruption was ubiquitous, and it was tolerated as long as the perpetrator was a regime insider. However, all regime supporters did not benefit equally. In particular, the extended Eyadema family and members of certain northern ethnic groups benefitted more. Important and lucrative political and administrative positions were filled by northerners, especially those from the president's ethnic group, the Kabye. As Seely notes, "the RPT has always perpetuated a thin veneer of north-south cooperation while maintaining the real power in the hands of loyal northerners". ${ }^{51}$ This is echoed by Heilbrunn, who summarizes the situation in Togo as follows: "Although the party included supporters from southern Togo, most high-ranking officials were family members of Kabye from the president's home region. These individuals occupied the lucrative directorships of public enterprises and preferred posts in the army. ${ }^{.52}$ Additionally, all of the potentially independent powers like legislature and media as well as civil society organizations like trade unions were subordinated to the ruling party, thus giving Eyadema almost unlimited power. ${ }^{53}$

\subsection{Repression}

The army was probably the most important source of Eyadema's power. In his public speeches he frequently emphasized the role of the army and its symbiotic relationship 
with the population. ${ }^{54}$ The budget of the armed forces was constantly expanded, and the number of soldiers and casernes increased considerably over time. In short, the army was omnipresent in all spheres of public life. ${ }^{55}$ Most officers belonged to the Kabye ethnic group and were loyal to the president, who was both minister of defence and commander-in-chief of the armed forces. Although the government was largely composed of civilians to disguise the military character of the regime, high-ranking military personnel held important political and administrative positions in state enterprises and parastatals. ${ }^{56}$

Critics of the regime were intimidated, harassed, or jailed, and opposition demonstrations were repressed or violently crushed. The Eyadema regime committed grave human rights violations throughout its tenure. ${ }^{57}$

\subsection{Togo between change and continuity}

An analysis of the transitional period in the 1990s is beyond the scope of this article. It suffices to say that although the democratic transition failed, the political system nevertheless underwent certain changes. ${ }^{58}$ A multiparty system was introduced, and elections were held for the first time in 1998. Against a fragmented opposition, Eyadema emerged as the winner and went on to be re-elected in 2003. The process was marred by electoral violence, alleged vote-buying, and accusations of electoral fraud. In 2005, Gnassingbé Eyadema died. According to the constitution, the president of the National Assembly, Fambaré Natchaba, was entitled to become the head of an interim government. Natchaba had been the director of the cabinet under Eyadema from 1977 to 1981, when he fell out with the president and went into exile. Having returned in the transition period, he joined the ruling party and was made president of the National Assembly, but he never had the full trust of crucial RPT elites. This became undeniable when he was effectively locked out during the brief succession crisis of 2005: As Natchaba was out of the country when Eyadema's death was announced, the military elite immediately suspended the constitution, to avoid a "power vacuum", and declared allegiance to the new president, Faure Gnassingbé. ${ }^{59}$ To cement the change of power, the constitution was changed in an extraordinary parliamentary session, and Natchaba was not allowed to re-enter the country. Although the international community condemned the unconstitutional change of government, all protests and strikes were quashed. Faure ultimately stepped down to de-escalate the situation, before standing as a candidate in the elections only 60 days later. $\mathrm{He}$ won these elections, and then those of 2010 and 2015. However, each of these elections was tainted by accusations of electoral fraud and violence.

It is not entirely clear whether Eyadema himself groomed Faure as his successor. Eyadema had a large number of children, and although it appears that he actively promoted Faure's political career, intra-familial power struggles cannot be completely ruled out. Some observers argue that Faure was not only chosen because of his relatively extensive education but also because his mother came from the south. ${ }^{60}$ The latter point would suggest that he was well-suited to bridge the antagonism between the north and the south of the country.

\section{Togo under Faure Gnassingbé}

\subsection{Legitimation}

Faure Gnassingbé is often described as taciturn and introverted, and his style of rule is definitely less personalized than that of his father. ${ }^{61}$ It is, however, unclear where the 
real power is located: Is Faure the undisputed leader, or is he controlled by old regime cadres in the background? According to observers, Faure is surrounded by an informal network of core regime supporters who make all the crucial decisions. ${ }^{62}$ It is also clear that, while he cannot credibly claim to have inherited the supernatural qualities that his father purported to possess, secret rituals of power still play a role: The ceremonies at the Sarakawa mausoleum continue to be held, and Faure is a member of the Togolese Freemason lodge. In African Freemasonry, secret rituals are used to foster elite integration and cohesion. ${ }^{63}$ Faure himself emphasizes continuity and change. On the one hand, he continues to present Togo as a peaceful and prosperous country. Against the background of improving macroeconomic indicators, these claims have a certain credibility. On the other hand, Faure has tried to distance himself somewhat from his father by presenting himself as a reformer. As the literature on electoral authoritarianism has often argued, elections and institutions play an important role in establishing regime legitimacy. ${ }^{64}$ In this vein, Faure used the 2005 elections to legitimize his unconstitutional takeover. Although the conduct of elections has improved, there are still irregularities, and the regime exerts tight control over the electoral calendar. ${ }^{65}$ International observers found the 2005 elections to be seriously flawed, but the 2010 polls were described as calm. ${ }^{66}$ Although the opposition has contested each election result, Faure can claim to have increased the credibility of the electoral process. Another reform in 2013 involved the renaming of the RPT party as UNIR (Union pour la République). According to observers, however, the party merely changed its name, while the structures remained largely the same. ${ }^{67}$ Furthermore, important positions in the party are still held by ethnic Kabye. ${ }^{68}$

\subsection{Co-optation and patronage}

Patronage remains a pillar of the regime, and loyalists are still rewarded with posts and positions. Faure has brought new and younger people into the ruling coalition, many of whom are former fellow students from the Lyceum in Kara and are personally loyal to him. Nonetheless, he cannot afford to alienate the old guard, and many of the RPT cadres from his father's era are still influential. ${ }^{69}$

A new form of elite co-optation was introduced by the accord that was signed between the ruling party and the UFC (Union des Forces de Changement) in 2010. Under Gilchrist Olympio, son of Togo's first president Sylvanus Olympio, the UFC was the most important opposition party. In the run-up to the 2010 elections, an internal leadership struggle broke out. When his opponent, Jean-Pierre Fabre, was nominated as the party's presidential candidate, Gilchrist struck a deal with Faure to form a government of national unity. As a reward, UFC members were nominated for high-ranking positions such as ministers and ambassadors. This move was unacceptable to a large part of the opposition and led to the founding of the ANC (Alliance nationale pour le changement) by Jean-Pierre Fabre. For Faure, the unity accord had several benefits: He neutralized a part of the opposition and could at the same time claim to have reconciled Togo's two leading political families, the Gnassingbé dynasty and the oppositional Olympio dynasty. The UFC gained a number of lucrative posts but alienated its core constituency and was reduced to only two deputies in the current parliament. Obviously, the weakness of the opposition contributes greatly to the limited political change in Togo, ${ }^{70}$ or, from the perspective of a Togolese opposition politician: "the main reasons for Faure's victory is the division of the opposition". 
Given the limited gains of being a member of a small opposition party, ambitious politicians in search of their own career advancement often find it more attractive to join the ruling party. ${ }^{72}$

In addition to elite co-optation, mass patronage remains an important factor for the survival of the regime. Money and other material benefits are channelled to chiefs and other locally influential persons, and huge construction projects were started just before the 2010 elections. UNIR also sold packages of pasta and rice bearing the party emblem or a picture of the president for a dumping price. In this regard, Faure has simply continued the entrenched practices of vote-buying and manipulation.

\subsection{Repression}

Although the overall human rights situation has improved, a number of repressive incidents still occur, like the excessive use of force against peaceful protesters or the arbitrary banning of demonstrations. ${ }^{73}$ Additionally, rebellious opposition politicians still face various forms of repression like arbitrary arrest and false accusations. ${ }^{74}$

The targets of repression have included not only regime opponents but also regime insiders. The most prominent example is Kpatcha Gnassingbé, a half-brother of Faure who was arrested in 2009. Kpatcha, who had his own network of supporters in the RPT and the military, was believed to be a guarantor of northern influence in the regime, whereas Faure was perceived as potentially shifting the power balance to the south. ${ }^{75}$ Civil society groups used the "Affaire Kpatcha" as one of their rallying issues in their fight against torture and human rights abuses. ${ }^{76}$ Although the awareness to human rights abuses has risen, civil society as a whole remains politicized and weak. ${ }^{77}$

A reform of the security sector was announced in 2013, but it primarily served the purpose of replacing some officers with individuals loyal to the president. ${ }^{78}$ A real reform of the security sector - which would include putting the armed forces under civilian control - is still missing. ${ }^{79}$ Thus, although the overall situation for civil liberties has improved, repression remains an important pillar of stability.

\section{The National Assembly}

As detailed in Section 4, the data used in the quantitative analysis were collected in the current parliament of Togo. Voting in Togo takes place under a party list-proportional representation system in 31 constituencies with two to five seats. ${ }^{80}$ The parliament has 91 members, 62 of whom belong to the ruling UNIR party; the others belong to one of the small opposition groups in the parliament. For the purposes of this article, all opposition parties are grouped together in one category. The position of the UFC is somewhat ambiguous, but it considers itself an opposition party and is therefore counted as such.

The full network that was constructed from the MPs' survey responses is displayed in Figure 1.

Nodes are coloured according to whether the deputy belongs to the government or the opposition, with the size of the node indicating in-degree centrality. Centrality as a concept in social network analysis describes the position of individual nodes in a network; in-degree centrality as applied here simply denotes the number of times an MP was nominated as a discussion partner by a fellow MP. The most central actor, a UNIR deputy, has 26 ties. 

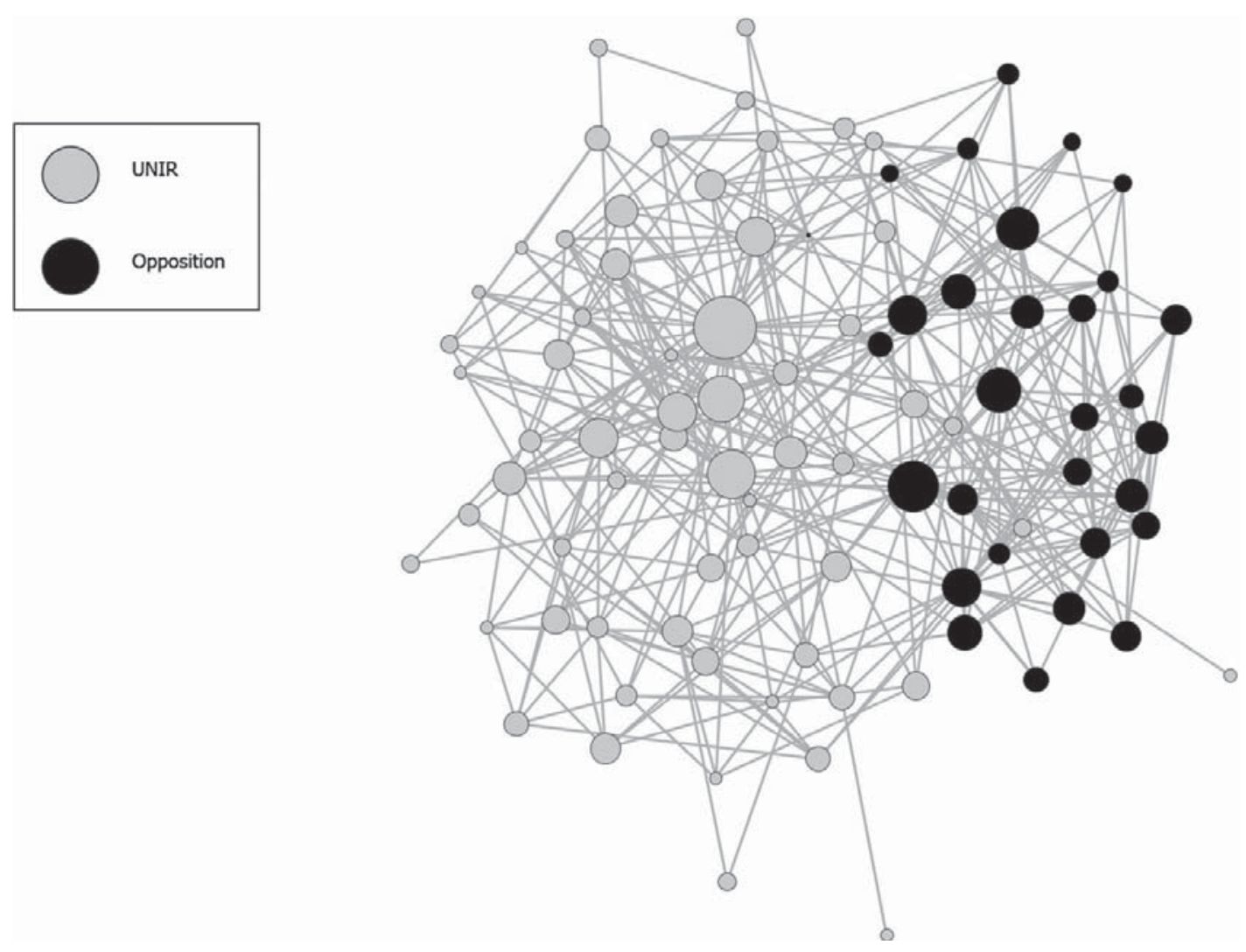

Figure 1. Central actors in the national assembly.

The data set also contains basic biographical information. ${ }^{81}$ In order to obtain information about their careers, we asked our respondents to indicate whether they held a high-ranking position in the political, public or private sector before becoming an MP. Since no information on typical careers of Togolese MPs was available, the question was formulated openly. The answers were hand-coded afterwards and assigned to one of the following categories: political sector, administration, private sector, social sector, and security (see Table 1). ${ }^{82}$ For the variable "family", the respondents were asked whether one of their family members has held or is currently holding an important position in the political, public, or private sector. The answers were also handcoded. Since this article only intends to capture the idea that MPs might stem from "powerful families" (which could also be an indication of personalized clientelism), information on the type of position and the family relationship are not shown here.

Table 1 compares the careers of government and opposition MPs and reveals enormous differences. Many UNIR deputies have held important positions in the past, most notably in the political and administrative sectors. The number of positions held in the

Table 1. Positions in various sectors prior to election to parliament, in percent.

\begin{tabular}{lrc}
\hline & UNIR & Opposition \\
\hline Political sector & 39.6 & 9.9 \\
Administration & 36.3 & 13.2 \\
Private economy & 9.9 & 6.6 \\
Social sector & 20.9 & 7.7 \\
Security sector & 1.1 & - \\
Educational sector & 13.2 & 8.8 \\
Family & 34.1 & 13.2 \\
\hline
\end{tabular}


past ranges from 1 to 6 for the political sector, and 1 to 7 for administration. Moreover, many MPs have been active in more than one sector in the past. It is not unusual for MPs to have been ministers and/or directors of a parastatal before being elected to parliament. Two deputies previously served in high-ranking positions at the port of Lomé. This is interesting because, as discussed in Section 5, the huge incomes generated by this port were in the past used as a patronage reservoir. Surprisingly few MPs come from the security sector; in fact, there is only one former police officer in the National Assembly. Two other deputies have family members in the army - in one of the cases, the respective family member holds one of the highest positions in the armed forces. This indicates that while there is still a link between the political and the military sector, political positions are mostly staffed with civilians. The big caveat here is that the data are limited to the National Assembly and do not specifically address the cabinet or the inner informal circle of the regime.

Opposition deputies have held considerably fewer important positions in the past, and only a limited number of them have family members in important positions.

Furthermore, there are differences between government and opposition with regard to regional and ethnic origin. As 56.5\% of UNIR MPs come from the north of the country and $43.6 \%$ come from the south, UNIR's northern bias is not as large as expected. The opposition, however, has a clear southern bias, with $72.4 \%$ of MPs originating from this region. In addition, $7 \%$ are ethnic Kabye, and all of them belong to the ruling party.

While these descriptive statistics tell us something about the composition of the Togolese elite, they show nothing of the distribution of power within this elite. The purpose of the quantitative network analysis is therefore to analyse whether actors with certain attributes have greater prestige, that is, a higher probability of being chosen as a discussion partner. In the models in Table 2, this is operationalized as the number of incoming ties, that is, the coefficients relate to a node's probability of receiving a tie. Before we turn to these models, we can formulate some hypotheses on the basis of the qualitative part of the article. As has been shown in Sections 5 and 6, Gnassingbé Eyadema's hold on power relied on a small clique of regime insiders who were predominantly of northern origin. More specifically, the most important positions were staffed with ethnic Kabye. From this, the first two hypotheses can be formulated:

H1: A northern origin increases the likelihood of being chosen as a political discussion partner.

H2: Being an ethnic Kabye increases the likelihood of being chosen as a political discussion partner.

To account for the continuing presence of old regime stalwarts, an index of power was constructed; this simply sums up the number of high-ranking positions that an individual held in the past (see also Table 1). In addition, a disaggregated version of the power variable was created that separately sums up the number of positions held in the individual sectors: politics, administration, security, private economy, social sector, and education. It is assumed that people who have held many important positions possess more prestige than political newcomers.

H3: The more high-ranking political positions a deputy has held in the past, the more likely he or she is to be chosen as a discussion partner. 
Table 2. ERGM of tie formation in the Togolese parliament.

\begin{tabular}{|c|c|c|c|c|}
\hline & Model 1 & Model 2 & Model 3 & Model 4 \\
\hline Edges & $\begin{array}{r}-11.43 \\
(10.33)\end{array}$ & $\begin{array}{c}-3.03^{* * *} \\
(0.16)\end{array}$ & $\begin{array}{l}-3.27^{* * *} \\
(0.16)\end{array}$ & $\begin{array}{c}-3.47^{* * * *} \\
(0.18)\end{array}$ \\
\hline Reciprocity & & & $\begin{array}{l}1.27^{* * *} \\
(0.19)\end{array}$ & $\begin{array}{l}1.3^{* * *} \\
(0.19)\end{array}$ \\
\hline Homophily & & & $\begin{array}{l}0.7^{* * * *} \\
(0.08)\end{array}$ & $\begin{array}{l}0.7^{* * * *} \\
(0.08)\end{array}$ \\
\hline North & $\begin{array}{r}0.00 \\
(0.02)\end{array}$ & & & \\
\hline Kabye & & $\begin{array}{l}0.75^{* * * *} \\
(0.18)\end{array}$ & $\begin{array}{l}0.37^{* *} \\
(0.12)\end{array}$ & $\begin{array}{c}0.35^{* *} \\
(0.12)\end{array}$ \\
\hline Power & $\begin{array}{l}0.13^{* * *} \\
(0.02)\end{array}$ & $\begin{array}{l}0.12^{* * *} \\
(0.02)\end{array}$ & $\begin{array}{l}0.07^{* * *} \\
(0.02)\end{array}$ & $\begin{array}{l}0.06^{* * * *} \\
(0.02)\end{array}$ \\
\hline UNIR & $\begin{array}{c}-0.5^{* * * *} \\
(0.1)\end{array}$ & $\begin{array}{c}-0.58^{* * *} \\
(0.1)\end{array}$ & $\begin{array}{l}-0.41^{* * *} \\
(0.06)\end{array}$ & $\begin{array}{c}-0.39 * * * \\
(0.07)\end{array}$ \\
\hline Gender & & & $\begin{array}{r}0.00 \\
(0.09)\end{array}$ & \\
\hline Legislative periods & & & & $\begin{array}{c}0.16^{* *} \\
(0.06)\end{array}$ \\
\hline GWESP $=0.1$ & & & $\begin{array}{l}1.13^{* * *} \\
(0.09)\end{array}$ & $\begin{array}{l}1.13^{* * *} \\
(0.09)\end{array}$ \\
\hline GWDSP $=0.1$ & & & $\begin{array}{l}-0.19^{* * *} \\
(0.02)\end{array}$ & $\begin{array}{c}-0.19^{* * * *} \\
(0.02)\end{array}$ \\
\hline AIC & 3455 & 3440 & 2928 & 2920 \\
\hline $\mathrm{BIC}$ & 3483 & 3468 & 2991 & 2983 \\
\hline
\end{tabular}

Note: ${ }^{* *} p<0.001,{ }^{* *} p<0.015,{ }^{*} p<0.05,{ }^{+} p<0.1$.

Given the dynastic character of politics in Togo, it can also be assumed that people from powerful families have more prestige than others. Therefore, the variable "family" reflects the number of family members who have held high-ranking positions or are currently holding such positions in any of the sectors.

H4: MPs with more family members who have held/currently hold high-ranking positions are more likely to be chosen as discussion partners. ${ }^{83}$

Furthermore, control variables are added: gender, political affiliation (government or opposition), and the number of legislative periods that the MP has been a member of the National Assembly. ${ }^{84}$ These controls not only assume that there are differences in the prestige of government and opposition MPs but also that men, as well as more experienced MPs, will be more likely to be chosen as discussion partners.

All models contain the term "edges", which adds a statistic equal to the number of edges in the network. ${ }^{85}$ Model 1 contains "power" and "north", controlling for government and opposition with "government" coded as 0 and "opposition" coded as 1 . In contrast, Model 2 replaces "north" with Kabye. Since the Kabye are an ethnic group of northern origin, these terms are not included together in a model. The power variable is highly significant in both models. However, while Model 1 does not show a significant effect for northern origin, Kabye MPs are significantly more likely to be chosen as discussion partners (Model 2). In addition, the negative effect observed for the UNIR variable indicates that opposition MPs are more likely to receive a tie than government MPs. To investigate whether these results hold with the addition of control variables, Model 3 adds variables to Model 2: "Reciprocity" controls for the likelihood of a reciprocated tie; "Homophily" shows whether MPs seek contacts in their own camp, whether UNIR MPs are more likely to choose another UNIR member as a discussion 
partner and vice versa for opposition MPs; and "Gender" controls whether men are more likely to receive a tie than women. GWESP (Geometrically Weighted Edgewise Shared Partners) and GWDSP (Geometrically Weighted Edgewise Shared Partners) are included together to control for transitivity. Transitivity captures the idea that triads have a tendency of closure: friends of a friend are also likely to become friends, or, in other words if MP A is connected to MP B and actor C, it is very likely that a connection between $\mathrm{B}$ and $\mathrm{C}$ will also emerge. While "Kabye", "power", and "UNIR" remain significant following these additions, gender does not seem to be a determinant for tie formation. Hence, Model 4 replaces the non-significant gender variable with a variable that measures the number of legislative periods that an MP has served in the National Assembly. As the length of legislative tenure obviously increases the likelihood of being chosen as a discussion partner, Model 4 fits the data reasonably well and can be seen as the model with the highest predictive power in this series. The GWESP term is positive and significant, indicating that two MPs who are themselves connected are more likely than by chance to have multiple partners in common. The insignificant GWDSP term measures the probability to which two unconnected MPs who have one contact in common will also have other contacts in common. This indicates that there is transitivity in the network. The homophily terms remain, however, significant and tell us that social selection processes determine the choice of discussion partners despite the tendency to link up with a friend's friend. ${ }^{86}$

Models 5 and 6 are interaction models that disaggregate the power variable into the positions held in the individual sectors according to government or opposition. An interaction variable was constructed for each of these variables by multiplying them with the value for government and opposition (government $=1$, opposition $=0$ in Model 5, and the reverse in Model 6). For UNIR MPs, we see that political positions are the most important determinant of tie formation, but the variable family is not significant (Table 3).

Table 3. Interaction models.

\begin{tabular}{|c|c|c|}
\hline & Model 5 UNIR & Model 6 opposition \\
\hline Edges & $\begin{array}{c}-3.07^{* * *} \\
(0.12)\end{array}$ & $\begin{array}{c}-3.12^{* * *} \\
(0.11)\end{array}$ \\
\hline Political sector & $\begin{array}{l}0.06^{*} \\
(0.02)\end{array}$ & $\begin{array}{l}0.03 \\
(0.03)\end{array}$ \\
\hline Administration & $\begin{array}{c}-0.02 \\
(0.02)\end{array}$ & $\begin{array}{c}-0.03 \\
(0.05)\end{array}$ \\
\hline Private economy & $\begin{array}{c}-0.05 \\
(0.09)\end{array}$ & $\begin{array}{l}0.05 \\
(0.09)\end{array}$ \\
\hline Social sector & $\begin{array}{r}-0.1^{+} \\
(0.06)\end{array}$ & $\begin{array}{l}0.09 \\
(0.06)\end{array}$ \\
\hline Security sector & $\begin{array}{c}-0.28 \\
(0.24)\end{array}$ & \\
\hline Educational sector & $\begin{array}{c}-0.06 \\
(0.06)\end{array}$ & $\begin{array}{l}0.05^{+} \\
(0.03)\end{array}$ \\
\hline Family & $\begin{array}{l}0.02 \\
(0.04)\end{array}$ & $\begin{array}{l}0.02 \\
(0.06)\end{array}$ \\
\hline GWESP $=0$ & $\begin{array}{l}1.57^{* * *} \\
(0.08)\end{array}$ & $\begin{array}{l}1.57^{* * *} \\
(0.08)\end{array}$ \\
\hline GWDSP $=0$ & $\begin{array}{c}-0.18^{* * *} \\
(0.02)\end{array}$ & $\begin{array}{c}-0.18^{* * *} \\
(0.02)\end{array}$ \\
\hline AIC & 3113 & 3116 \\
\hline $\mathrm{BIC}$ & 3183 & 3179 \\
\hline
\end{tabular}

Note: ${ }^{* * *} p<0.001,{ }^{* *} p<0.015,{ }^{*} p<0.05,{ }^{+} p<0.1$. 
Thus, hypotheses $\mathrm{H} 2$ and $\mathrm{H} 3$ are confirmed. By contrast, we find no evidence for $\mathrm{H} 1$ and $\mathrm{H} 4$.

\section{Conclusion}

This article has analysed continuity and change in the electoral autocracy Togo. The ruling regime, however, has remained in place despite the death of longtime ruler Gnassingbé Eyadema. From the combined qualitative and quantitative analysis, a number of conclusions can be drawn.

First of all, modern autocracies - especially those which have practiced hereditary succession - are torn between change and continuity. Eyadema relied upon a combination of strategies: the cult around the leader, repression, and selective material benefits to regime supporters, especially the Kabye ethnic group. His son Faure Gnassingbé had to adapt these strategies. While portraying himself as a reformer, he still works with old regime cadres. Thus, while a good deal of power remains in the hands of the Kabye ethnic group, changes to political institutions such as the National Assembly or the renaming of the ruling party are exploited to create the impression of a reformed regime. In this way, the unity accord with the UFC has also helped to enhance Faure's legitimacy. However, the threat of repression remains persistently high. In addition, the government's superior financial resources allow it to distribute benefits to strategically important social groups and individuals.

The quantitative analysis suggests that people who have held important positions in the past still play a significant role in the regime elite. Interestingly, however, no indication of northern dominance has been found. This gives credit to speculations that the power balance under Faure is shifting away from the north. The interpretation of this finding is difficult, as a more equitable regional balance can be seen as a positive sign of the greater dispersion of power; nonetheless, the significant role of the Kabye indicates that power is still concentrated in one ethnic group and familial dynasty. There are many things that could still be more closely investigated, for example the candidate nomination processes of Togo's political parties, to understand how elite power is reproduced at the intra-party level.

What can we learn from these findings? On the theoretical level, it shows that although all authoritarian regimes rest on the same pillars of stability - legitimation, co-optation, and repression - the actual mix of these strategies varies and can be adapted according to the needs of regime survival. If a dictator's son is capable of adapting his strategies, he may be able to successfully stabilize the regime he has inherited. On the problem of regime classifications, the article has shown that personal charisma cannot be inherited. Faure definitely does not possess the same allegedly supernatural qualities of his father. This casts doubt on the continuing classification of Togo as a personalist regime by Geddes, as it ignores the differences between father and son. Thus, the article argues that we need to rethink and refine our sub-types of authoritarian regimes. Third, and this is perhaps the most important finding, it is shown that the inner circle of the regime - the leader and his closest allies - continue to determine the fate of autocratic regimes despite electoral reforms. Future research should thus pay more attention to the real distribution of power between the key figures in the political system. Social Network Analysis, as proposed here, can show one way forward to uncovering these power structures. We need, however, more case-based knowledge from which an encompassing theory of authoritarian elite politics can be built. This 
would greatly help our understanding of regime trajectories and allow to identify and assess the possibilities of democratic change.

\section{Notes}

1. Attisso, Le Togo sous la dynastie des Gnassingbé, 46.

2. Geddes, "What Do We Know."

3. Geddes, Wright, and Frantz, "Autocratic Breakdown."

4. Brownlee, "Hereditary Succession."

5. Geddes, Wright, and Frantz, "Autocratic Breakdown."

6. Higley and Burton, Elite Foundations, 7.

7. Geddes, "What Do We Know."

8. Ibid., 121.

9. Ibid.

10. Hadenius and Teorell, "Pathways from Authoritarianism."

11. Wahman, Teorell, and Hadenius, "Authoritarian Regime Types Revisited."

12. Schedler, Electoral Authoritarianism.

13. Kailitz, "Classifying Political Regimes Revisited."

14. Available at http://sites.psu.edu/dictators/. See also Geddes, Wright, and Frantz, "Autocratic Breakdown."

15. Wahman, Teorell, and Hadenius, "Authoritarian Regime Types Revisited."

16. It remains unclear why the year 2004 marks the beginning of a new regime type. Unfortunately, the years between 1994 and 2003 are missing from Kailitz's classification.

17. Gerschewski, "The Three Pillars of Stability."

18. Ibid.

19. Ibid., $18-20$.

20. Ibid., 22.

21. Schatzberg, Political Legitimacy.

22. Ibid.

23. Bratton and van de Walle, "Neopatrimonial Regimes," 463.

24. Geddes, "What Do We Know."

25. Ibid.

26. Chabal and Daloz, Africa Works.

27. Ibid., 42 .

28. Bratton and van de Walle, "Neopatrimonial Regimes."

29. Geddes, "What Do We Know," 132.

30. Brownlee, "Hereditary Succession," 597.

31. Johnson and Onwuegbuzie, "Mixed Methods."

32. Leech and Onwuegbuzie, "A Typology."

33. Rohlfing, Case Studies.

34. Levitsky and Way, Competitive Authoritarianism, 27.

35. Burt, "Network Items and the General Social Survey."

36. Knoke and Burt, "Prominence."

37. Lusher, Koskinen, and Robins, "Introduction."

38. Robins and Lusher, "Simplified Account."

39. Okonofua, "Democratic Governance in the 'New' Republic of Togo," 87.

40. Toulabor, Le Togo sous Eyadéma.

41. Ibid., 37.

42. Attisso, Le Togo sous la dynastie des Gnassingbé, 41.

43. Ibid.

44. Toulabor, Le Togo sous Eyadéma, $110 \mathrm{ff}$.

45. Ibid.

46. Houngnikpo, Determinants of Democratization, 58.

47. Toulabor, Le Togo sous Eyadéma, 93.

48. Attisso, Le Togo sous la dynastie des Gnassingbé, 80ff.

49. Ibid. 
50. Ibid.

51. Seely, The Legacies of Transition Governments, 47.

52. Heilbrunn, "Togo: The National Conference," 228.

53. Okonofua, "Democratic Governance in the 'New' Republic of Togo," 87.

54. See, among others, Attisso, Le Togo sous la dynastie des Gnassingbé.

55. Siliadin, Togo, démocratie impossible?, 36.

56. Attisso, Le Togo sous la dynastie des Gnassingbé, 96.

57. Siliadin, Togo, démocratie impossible?; Seely, The Legacies of Transition Governments.

58. Seely, The Legacies of Transition Governments, 40.

59. Banjo, "Constitutional and Succession Crisis."

60. Interviews with a political observer and a journalist, Lomé, November 2014. For reasons of confidentiality, the names of all informants are withheld. Details can be obtained from the author upon request.

61. Interview with a leading UNIR member, Lomé, December 2015.

62. Interview with a political observer, Lomé, November 2014.

63. Interview with a political observer, Lomé, November 2014.

64. Gandhi, Political Institutions under Dictatorship.

65. Okonofua, "Democratic Governance in the 'New' Republic of Togo."

66. See EU-EOM, "Mission d'observation électorale de l'Union Européenne au Togo."

67. Interviews with a journalist and two political observers, Lomé, November 2014.

68. Interview with a leading opposition politician, Lomé, December 2015.

69. Interview with two political observers, Lomé, November 2014. Interview with a leading opposition politician, Lomé, December 2015.

70. Siliadin, Togo, démocratie impossible?, 77ff.

71. Interview with a leading opposition politician, Lomé, December 2015.

72. Akpabie, "Fragments de Reflexion," $246 f$.

73. https://www.amnesty.org/en/countries/africa/togo/report-togo/ [accessed 6 July 2016].

74. Interviews with two opposition MPs, Lomé, December 2015.

75. Attisso, Le Togo sous la dynastie des Gnassingbé, 148.

76. Millot, Société civile et construction démocratique au Togo, 33.

77. Ibid.

78. Bertelsmann Stiftung, BTI 2016 - Togo Country Report.

79. Toulabor, "Togo," $243 \mathrm{ff}$.

80. Roberts, "The Legislative Election in Togo."

81. For descriptive statistics see Appendix 2.

82. The goal of the question was to extract as much information on the careers as possible. Due to the lack of prior information on African MPs' careers, any pre-coding would have restricted the given answers to those categories that could be expected in the view of the researcher. To avoid this bias, the questionnaire collected information on positions deemed "high-ranking" by the respondents themselves. This generated rich data but necessitated a time-consuming coding process: for each answer, it had to be decided whether the information would be coded in a "high-ranking" position in one of the sectors given in Table 1 or a residual category of "other" positions. The category "political" contains mostly ministers and leading positions at the national party level. For the category "administration" only high positions in the administration were coded, for example directors of big parastatals. In the private sector, the positions are more diverse and do include, for example, owners of private enterprises - for many of these it was impossible to find out just how big these enterprises are. The important information here is not how successful a business was, but rather the mere fact that an MP had been active in this sector before being elected. The category "social" contains positions in social care and non-governmental organizations sectors, and "education" contains professors and headmasters of tertiary and secondary institutions.

83. A high number of consecutively held positions could also indicate that a person is not performing well and therefore constantly losing their job. In an electoral autocracy, however, nomination to high positions follows clientelistic criteria rather than professional merit. Therefore, it seems justified to assume that the number of positions held reflects the power of a person. Since only high-ranking positions are coded, the highest value of the power variable is 9 , and the mean is 3.8 . 
84. For a discussion of these control variables in an African context, see Osei and Malang, "Party, Ethnicity, or Region?"

85. The number of observations is 91 for each model. Although only $72 \mathrm{MPs}$ answered the questionnaire, all other MPs are included in the network because they were named by at least one other MP.

86. Comprehensive goodness of fit statistics are found in Appendix 1. A large number of networks is simulated. The distribution of some common network statistics is then compared to that of the observed data. The boxplots represent the distribution across all simulated networks; the dark line represents the distribution of the observed network (see Goodreau et al., "A Statnet Tutorial"). For the interpretation of the GWESP and GWDSP terms, see Hunter, "Curved Exponential Family Models."

\section{Bibliography}

Akpabie, A. A. "Fragments de Reflexion Sur Les Strategies de Conquête de Pouvoir de l'opposition Togolaise et La Panne de La Démocratie." Recherche Scientifique de l'Université de Lomé 16, no. 3 (2014): 237-250.

Attisso, Fulbert Sassou. Le Togo sous la dynastie des Gnassingbé. Paris: Editions L'Harmattan, 2012.

Banjo, Adewale. "Constitutional and Succession Crisis in West Africa: The Case of Togo." African Journal of Legal Studies 2, no. 2 (2008): 147-161.

Bertelsmann Stiftung. BTI 2016 Country Report - Togo. Gütersloh: Bertelsmann Stiftung, 2016.

Bratton, Michael, and Nicolas van de Walle. "Neopatrimonial Regimes and Political Transitions in Africa". World Politics 46, no. 4 (1994): 453-489.

Brownlee, Jason. "Hereditary Succession in Modern Autocracies." World Politics 59, no. 4 (2007): 595-628. Burt, Ronald S. "Network Items and the General Social Survey." Social Networks 6, no. 4 (1984): 293-339. Chabal, Patrick, and Jean-Pascal Daloz. Africa Works: Disorder as Political Instrument. London: James Currey, 1999.

EU-EOM. "Mission d'observation électorale de l'Union Européenne au Togo - Élection présidentielle Mars 2010.” Rapport final. Brussels: European Union Election Observation Mission (EOM), Togo.

Gandhi, Jennifer. Political Institutions under Dictatorship. Cambridge: Cambridge University Press, 2010.

Geddes, Barbara. "What Do We Know about Democratization after Twenty Years?" Annual Review of Political Science 2, no. 1 (1999): 115-144.

Geddes, Barbara, Joseph Wright, and Erica Frantz. "Autocratic Breakdown and Regime Transitions: A New Data Set.” Perspectives on Politics 12, no. 2 (2014): 313-331. 
Gerschewski, Johannes. "The Three Pillars of Stability: Legitimation, Repression, and Co-Optation in Autocratic Regimes." Democratization 20, no. 1 (2013): 13-38.

Goodreau, Steven M., Mark S. Handcock, David R. Hunter, Carter T. Butts, and Martina Morris. "A Statnet Tutorial." Journal of Statistical Software 24, no. 9 (2008): 1-27.

Hadenius, Axel, and Jan Teorell. "Pathways from Authoritarianism." Journal of Democracy 18, no. 1 (2007): 143-157.

Heilbrunn, John R. "Togo: The National Conference and Stalled Reform." In Political Reform in Francophone Africa, edited by John Frank Clark, and David E. Gardinier, 225-245. Boulder, CO: Westview Press, 1997.

Higley, John, and Michael G. Burton. Elite Foundations of Liberal Democracy. Oxford: Rowman \& Littlefield, 2006.

Houngnikpo, Mathurin C. Determinants of Democratization in Africa: A Comparative Study of Benin and Togo. Lanham, MD: University Press of America, 2001.

Hunter, David. "Curved Exponential Family Models for Social Networks." Social Networks 29, no. 2 (2007): 216-230.

Johnson, R. Burke, and Anthony J. Onwuegbuzie. "Mixed Methods Research: A Research Paradigm Whose Time Has Come.” Educational Researcher 33, no. 7 (2004): 14-26.

Kailitz, Steffen. "Classifying Political Regimes Revisited: Legitimation and Durability." Democratization 20, no. 1 (2013): 39-60.

Knoke, David, and Ronald S. Burt. "Prominence." In Applied Network Analysis: A Methodological Introduction, edited by Ronald S. Burt, and Michael J. Minor, 195-222. London: Sage Publications, 1983.

Leech, Nancy L., and Anthony J. Onwuegbuzie. "A Typology of Mixed Methods Research Designs." Quality \& Quantity 43, no. 2 (2007): 265-275.

Levitsky, Steven, and Lucan A. Way. Competitive Authoritarianism: Hybrid Regimes after the Cold War. Cambridge: Cambridge University Press, 2010.

Lusher, Dean, Johan Koskinen, and Garry Robins. "Introduction." In Exponential Random Graph Models for Social Networks: Theory, Methods, and Applications, edited by Dean Lusher, Johan Koskinen, and Garry Robins, 1-15. Cambridge: Cambridge University Press, 2012.

Millot, Antonine. Société civile et construction démocratique au Togo. Toulouse: Institut d'Etudes Politiques de Toulouse, These.

Okonofua, Benjamin A. "Democratic Governance in the 'New' Republic of Togo." In Democratic Contestation on the Margins: Regimes in Small African Countries, edited by Claire Metelits, and Stephanie Matti, 85-98. Lanham, MD: Lexington Books, 2015.

Osei, Anja, and Thomas Malang. "Party, Ethnicity, or Region?: Determinants of Informal Political Exchange in the Parliament of Ghana." Party Politics, 2016. Online first. doi.org/10.1177/ 1354068816663038.

Roberts, Tyson. “The Legislative Election in Togo, October 2007.” Electoral Studies 27, no. 3 (2008): 558-561.

Robins, Garry, and Dean Lusher. "Simplified Account of an Exponential Random Graph Model as a Statistical Model." In Exponential Random Graph Models for Social Networks: Theory, Methods, and Applications, edited by Dean Lusher, Johan Koskinen, and Garry Robins, 29-36. Cambridge: Cambridge University Press, 2012.

Rohlfing, Ingo. Case Studies and Causal Inference: An Integrative Framework. Houndmills, Basingstoke: Palgrave Macmillan, 2012.

Schatzberg, Michael G. Political Legitimacy in Middle Africa: Father, Family, Food. Bloomington and Indianapolis: Indiana University Press, 2001.

Schedler, Andreas. Electoral Authoritarianism: The Dynamics of Unfree Competition. Boulder, CO: Lynne Rienner, 2006.

Seely, Jennifer. The Legacies of Transition Governments in Africa: The Cases of Benin and Togo. New York: Palgrave MacMillan, 2009.

Siliadin, Jonas. Togo, démocratie impossible? Paris: Editions L'Harmattan, 2014.

Toulabor, Comi M. Le Togo sous Eyadéma. Paris: Karthala Editions, 1986.

Toulabor, Comi M. "Togo." In Security Sector Governance in Francophone West Africa: Realities and Opportunities, edited by Alan Bryden, and Boubacar N’Diaye, 229-254. Münster: LIT, 2011.

Wahman, Michael, Jan Teorell, and Axel Hadenius. "Authoritarian Regime Types Revisited: Updated Data in Comparative Perspective." Contemporary Politics 19, no. 1 (2013): 19-34. 


\section{Appendices}

\section{Appendix 1}

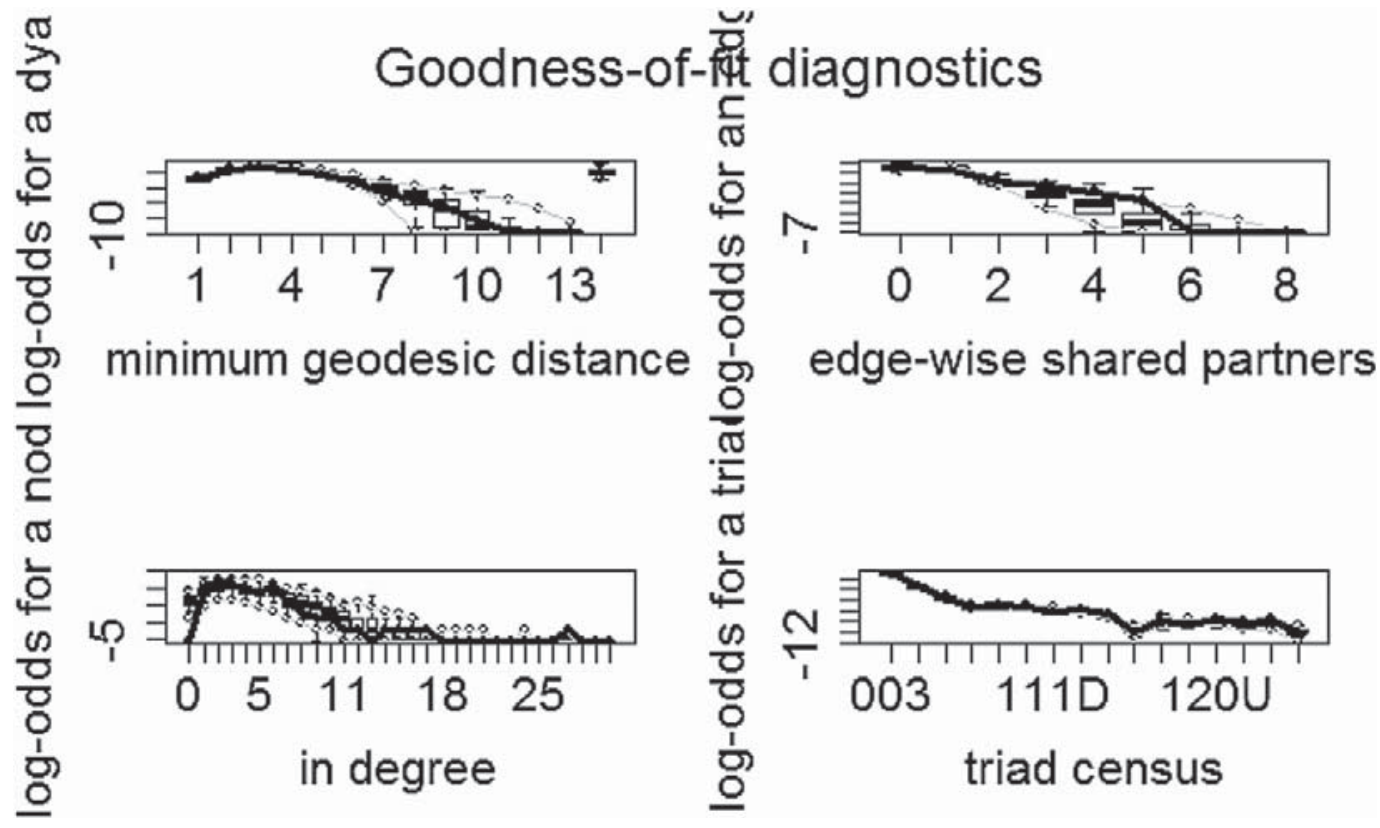

Sample statistics

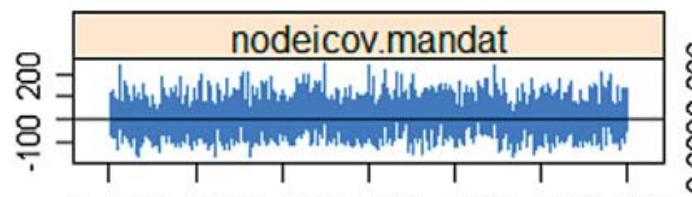

$0 e+001 e+072 e+073 e+074 e+075 e+076 e+07$

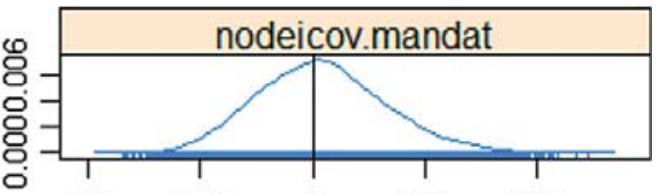

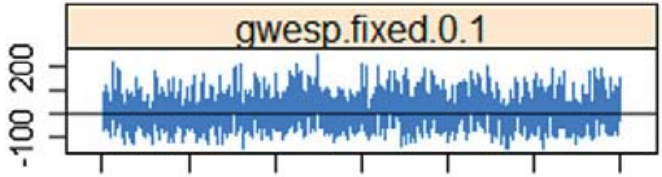

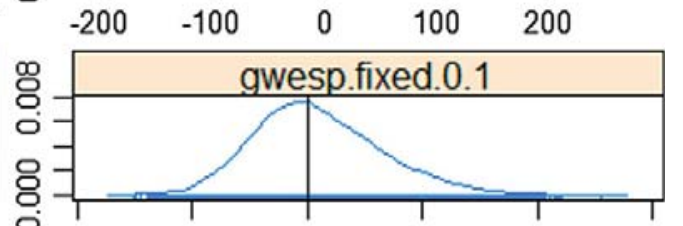

$0 e+001 e+072 e+073 e+074 e+075 e+076 e+07$
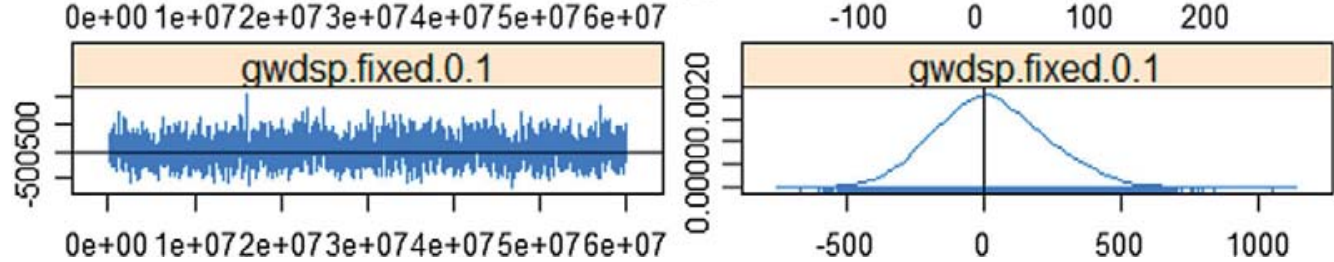
Sample statistics

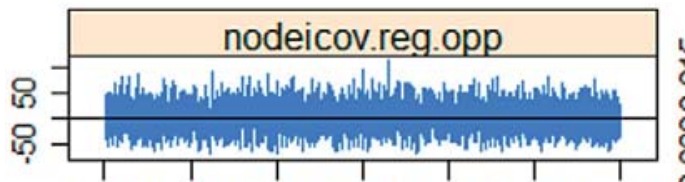

$0 e+001 e+072 e+073 e+074 e+075 e+076 e+07$
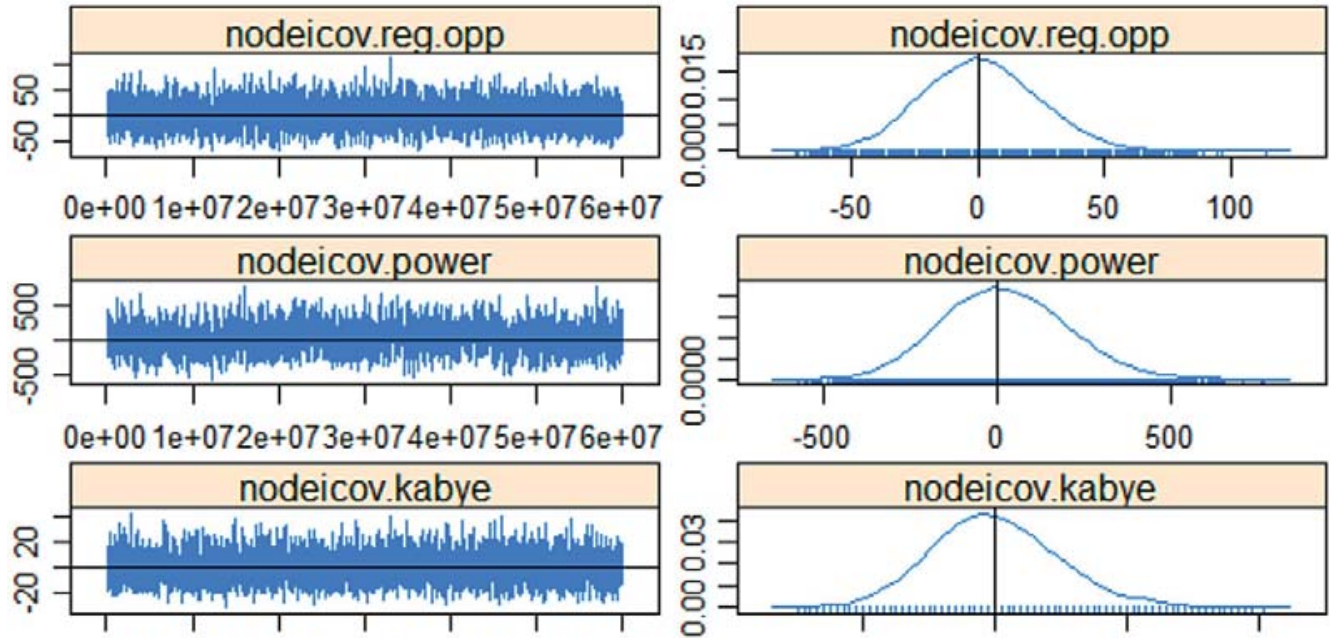

$0 e+001 e+072 e+073 e+074 e+075 e+076 e+07$

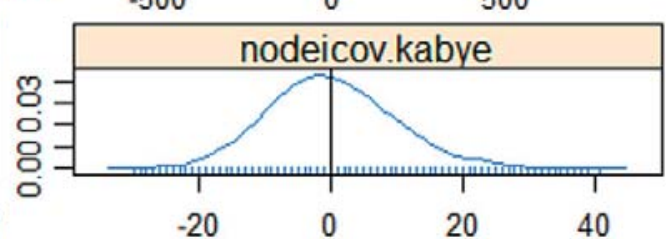

\section{Appendix 2. Descriptive statistics}

\begin{tabular}{|c|c|c|c|c|c|}
\hline Variable & Obs & Mean & Std. Dev. & Min & Max \\
\hline Gender & 91 & 0.1758242 & 0.3827795 & 0 & $\overline{1}$ \\
\hline Legislative periods & 91 & 1.21978 & 0.5121241 & 1 & 4 \\
\hline Kabye & 91 & 0.0549451 & 0.2291354 & 0 & 1 \\
\hline North & 91 & 0.5274725 & 0.5020106 & 0 & 1 \\
\hline Power & 91 & 3.879121 & 2.235249 & 0 & 9 \\
\hline Political sector & 91 & 1.021978 & 1.520073 & 0 & 7 \\
\hline Administration & 91 & 1.098901 & 1.513311 & 0 & 6 \\
\hline Social sector & 91 & 0.8131868 & 1.201037 & 0 & 7 \\
\hline Security sector & 91 & 0.032967 & 0.3144855 & 0 & 3 \\
\hline Education & 91 & 0.4175824 & 1.033505 & 0 & 7 \\
\hline Family & 91 & 0.7142857 & 0.8979695 & 0 & 4 \\
\hline
\end{tabular}

